\title{
CHAPTER 12 \\ BACKGROUND OF FORMING THE RELEVANT LEVEL OF ECONOMIC SECURITY OF THE ENTERPRISE: EFFICIENCY, INNOVATION, AND COMPETITIVENESS
}

\section{Fisunenko P. A.}

\section{INTRODUCTION}

Study of economic security at different levels of the economy began in the last thirty years of the past century when it became necessary to identify and respond to the threats and continues up today. The economic security of enterprises in foreign literature is called "ecosecent" (economic security of enterprise). In the Ukrainian literature concerning the definition of the essence of "economic security of the enterprise" concept at the present stage, there is a lot of opinions. The research of the conceptual-categorical apparatus in this area and the definition of the preconditions for the appropriate level of economic security of the enterprise formation are relevant.

Considering the basic prerequisites for the formation of the appropriate level of economic security of the enterprise, it is necessary to apply a systematic approach that allows investigating the causal relationships between economic security (purpose), the competitiveness of the enterprise (means) and efficiency (the ratio of income and expenditure, organizational and managerial efficiency), and the innovation of its activities (tools).

According to the World Economic Forum, Ukraine refers to efficiency-oriented economies at the level of competitiveness ${ }^{1}$. That is, the level of economic growth depends on efficiency. At this stage, it is necessary to introduce more efficient production processes, to improve the quality of products, to ensure the quality of higher education and training, an efficient market for goods and services, the sound functioning of the labour market, the development of the financial market, internal and external markets, and the ability to implement the

\footnotetext{
1 Позиція України в рейтингу країн світу за індексом глобальної конкурентоспроможності 2017-2018. Економічний дискусійний клуб. URL: http://edclub.com.ua/analityka/pozyciya-ukrayiny-vreytyngu-krayin-svitu-za-indeksom-globalnoyi-konkurentospromozhnosti-2 (дата звернення: 15.05.2019).
} 
latest technology. Also, the report published by the World Economic Forum points to the need for a systematic approach to improving competitiveness, which is especially relevant when it comes to innovation, because strong innovation orientation can provide a "jump" in the economies of low- and middle-income countries. As the research has shown, in the process of ensuring an adequate level of economic security of an enterprise, one can distinguish the main preconditions competitiveness, efficiency, and innovation, and consider them as a goal, means, and tools for its achievement.

\subsection{An overview of theoretical and methodological approaches to the definition of the essence of economic security of the enterprise}

Many Ukrainian scientists are involved in the study of the economic security of the enterprise, in particular, B. Andrushkov, A. Baranovsky, V. Vasiltsev, S. Varnalius, A. Vlasyuk, V. Gayets, B. Gunnsky, S. Dovbnia, F. Evdokimov, I. Ivanyuta, A. Zaichychsky, O. Zhikhor, A. Kirienko, G. Kozachenko, T. Kuzenko, V. Muntian, V. Ponomarev, O. Lyashenko, T. Sokolenko, and many others.

Given a large number of investigations in this field in order to study the essence of the concept of "economic security of the enterprise", it is necessary to carry out its semantic analysis as a phrase from three concepts: "economic", "security", "enterprise".

In the dictionary ${ }^{2}$, the term "economic" is understood as, firstly, "which concerns the totality of socio-industrial relations, economic life, etc. (economic struggle, economic crisis, economic life, economic journal, economic geography), and secondly, as "profitable" in economic terms (economic project, economic regime, economic refrigerator, economic technology). Semantically, the word "economic" is an adjective of the word "economy" . Economy (from Greek. Oikonomikë the art of conducting a household) - a set of economic relations in human society; economy of the enterprise, region, country, group of countries or the world; a complex of social sciences that explores the abovementioned economy and a set of economic relations ${ }^{4}$.

With regard to the concept of "security", then in the new interpretive dictionary of the Ukrainian language, it is defined as a state

\footnotetext{
${ }^{2}$ Slovopediy. URL: http://slovopedia.org.ua/32/53397/30739.html

${ }^{3}$ Словник української мови. URL: http://sum.in.ua/s/ekonomichnyj

4 Словарь финансовых терминов. Программа поиска толкований слов «Interpretatio». URL: http://inetio.org/.
} 
when someone or something nothing threatens ${ }^{5}$. In this paper ${ }^{6}$, security refers to the conditions in which a complex system is present when the action of external factors and internal factors does not lead to processes that are considered negative in relation to this complex system in accordance with existing, at this stage, needs, knowledge, and representations.

A number of normative documents also defines the term: "Safety the absence of unacceptable risk associated with the possibility of causing any damage to life, health, and property of citizens, as well as for the environment"7; safety means the absence of unacceptable risk associated with the possibility of causing damage and/or damage ${ }^{8}$ and a number of other specific definitions relating to aviation, mining and smelting complex, railway transport, regulations of explosive materials of industrial purpose. In Greek, "security" means "to have a situation", that is, security is a state of the subject in which the probability of a change in the properties and parameters of its environment inherent to this subject is insignificant, less than a certain interval ${ }^{9}$.

The third component of the phrase is the term "enterprise". The Law of Ukraine "On Enterprises in Ukraine" states that an enterprise is an independent economic entity that has the rights of a legal entity and carries out production, research, and commercial activity in order to receive the corresponding profit (income). In the current normative document, the Commercial Code of Ukraine states that an enterprise is an independent economic entity created by a competent authority of state power or a local self-government authority or other entities to meet social and personal needs through the systematic implementation of industrial, research, trade, other business activities in the manner prescribed by this Code and other laws. In educational literature, it is noted that the enterprise is an organizationally separate and economically independent branch of the manufacturing sphere of the national economy specializing in the production of products, the

\footnotetext{
${ }^{5}$ Новий тлумачний словник української мови: В 4-х т. / Укл.: В. В. Яременко, О. М. Сліпушко. Київ : Аконіт, 2001. 911 с.

6 Заплатинський В. М. Логіко-детермінантні підходи до розуміння поняття «Безпека». Вісник Кам'янець-Подільського національного університету імені Івана Огієнка. Фізичне виховання, спорт $i$ здоров'я людини. 2012. Випуск 5. С. 90-98.

7 Правила обстежень, оцінки технічного стану та паспортизації виробничих будівель і споруд. URL: https://zakon.rada.gov.ua/laws/show/z0423-98

${ }^{8}$ Кодекс систем розподілу. URL: https://zakon.rada.gov.ua/laws/show/v0310874-18/ed20180314\#n28

9 Словарь финансовых терминов. Программа поиска толкований слов «Interpretatio». URL: http://inetio.org/.
} 
execution of works, and the provision of services ${ }^{10}$. In the book under the editorship of S. Pocropivny, it is stated that the enterprise is an organizationally isolated and economically independent main (primary) link of the manufacturing sphere of the national economy, which produces products (performs work or provides paid services) ${ }^{11}$.

Let's consider the modern and most actual thoughts of national specialists regarding the definition of "economic security of the enterprise" as a result of combining the semantic meanings of the three concepts under consideration and establish the main characteristics used in determining the essence of the complex concept "economic security of the enterprise".

So, G. Kozachenko considers the economic security of the enterprise "as harmonization in time and space of economic interests of the enterprise with the interests of the external entities involved with it, operating outside the enterprise" $" 12$. But in this case, the tools and means to achieve this harmonization are not considered.

F. Evdokimov and O. Misina characterize economic security in terms of the impact of the external and internal environment of the enterprise. So, in terms of the environment (various market agents), the company's economic security is a complex expression of the degree of reliability of the company as a partner in the production, financial, commercial, and other economic relations. From the standpoint of the internal environment, the company's economic security is the protection of its potential (production, organizational, technical, financial, economic, social) from the negative impact of external and internal factors, direct or indirect economic threats, as well as the ability of the subject to reproduce ${ }^{13}$. In this case, in our opinion, there are no tools and facilities for ensuring the security of the potential.

In another work, F. Evdokimov notes that the assessment of the economic situation of the enterprise, the absence of a threat of bankruptcy is a necessary but not sufficient condition for an assessment of economic security. The author notes that we should talk about the

\footnotetext{
${ }^{10}$ Бойчик I. М Економіка підприємства: підручник. Київ : Кондор-Видавництво, 2016. 378 с.

${ }^{11}$ Економіка підприємства : підручник / За заг. ред. С. Ф. Покропивного. Вид. 2-ге, перероб. та доп. Київ : КНЕУ, 2001. 528 с.

${ }^{12}$ Козаченко Г. В., Пономарьов В. П. Економічна безпека підприємств: сутність і передумови формування. Теорія та практика управління у трансформаиійний період. Т. 3. Донецьк : ІЕП НАН України, 2001. С. 3-7.

${ }_{13}$ Евдокимов Ф. И., Мизина Е. В. Экономическая устойчивость предприятия как фактор его безопасности. Наукові праиі Донецького державного технічного університету. Серія: економічна. Випуск 37. Донецьк, ДонНТУ, 2001. С. 16-25.
} 
sustained economic development of the enterprise for a long-term perspective, the identification of risk factors in advance in all directions of its activity. In this case, economic security is understood by the author as harmonization of production, marketing and reproductive processes of the enterprise, in which the probability of unwanted economic condition, estimated by changes in regulated parameters, does not exceed a predetermined level ${ }^{14}$. This definition, in our opinion, does not indicate at the expense of what and thanks to whom (i.e. means and performers) harmonization is achieved.

N. Yatsenko and S. Mikhailuk consider the economic security of the enterprise as a subsystem of national economic security and define it as the economic state of the enterprise, consistent with the internal and external changes in financial and economic activity, not related to forcemajeure circumstances ${ }^{15}$.

The Big Economic Dictionary has the following definition: economic security is the state of legal, economic relations, organizational links, material and intellectual resources of the enterprise, which guarantees the stability of its operation, financial and commercial success, progressive scientific and technical and social development ${ }^{16}$. It should be noted that this definition does not specify the preconditions for this state.

T. Sokolenko considers economic security as a condition in which the strategic potential of the company is near the limits of adaptability, and the threat of loss of economic security increases as the degree of adaptability of the strategic potential reaches the marginal zone ${ }^{17}$. As factors influencing the economic safety of the enterprise, the author identifies the degree of the possible risk of making managerial decisions and claims the need to fall into the zone of permissible risk (when the magnitude of possible losses does not exceed the magnitude of possible profits). In this case, due attention was paid not only to risk but also to other factors of influence, in particular, efficiency and innovation of the enterprise.

\footnotetext{
14 Евдокимов Ф. И. Экономическая безопасность - необходимое звено в планировании развития предприятия/ Матеріали науково-практичної конференції «Донбас 2002: наука $i$ техніка виробництву», 5-6 лютого 2002, Донецьк. С. 966-969.

15 Яценко Н. М., Михайлюк С. О. Регіональна економічна безпека у контексті національної економічної безпеки. Наукові праці Донецького державного технічного університету. Серія: економічна. Випуск 37. Донецьк, ДонНТУ, 2001. С. 78-82.

16 Большой экономический словарь. Под ред. А. Н. Азриляна. 5-е изд., доп. и перераб. Москва, 2002.

${ }^{17}$ Соколенко Т. М. Економічна безпека підприємства в умовах транзитивної економіки. URL: http://intkonf.org/kand-ped-n-sokolenko-tm-ekonomichna-bezpeka-pidpriemstva
} 
In the normative document ${ }^{18}$, under the economic security of the enterprise, the state understands the state of its defence against the negative impact of external and internal threats, destabilizing factors, which ensures a stable implementation of basic economic interests and objectives of the statutory activities. Again, it is not clear what exactly determined the ensured security status.

T. Ivanyuta and A. Zaichychsky in their work under the economic security of an enterprise mean the state of the economic entity, in which, at the most efficient use of available resources, it achieves prevention, weakening or protection against existing threats and threats or other unforeseen circumstances, and basically achieves business objectives in conditions of competition and economic risk ${ }^{19}$. In this definition, there is a mention of efficiency but it only refers to the efficiency of the use of resources and does not mention the innovation of the enterprise.

In the monograph, $\mathrm{T}$. Vasyltsiv ${ }^{20}$ under the economic security of an enterprise means the level of viability of the business entity during the life cycle of its operation, which simultaneously guarantees the fulfilment of the mission and objectives of the enterprise. In addition, the inevitable characteristics of economic security of the business entity, according to scientists, are the access to resources and markets, the state of protection from external and internal risks, the level of economic efficiency of functioning, as well as the ability of the enterprise to develop. Indeed, this approach describes important functional areas and functional elements of the enterprise but does not reflect fully the preconditions for ensuring economic security.

Authors L. Korchevskaya and G. Josan define economic security terminologically as the ability of subjects of socio-economic relations to protect economic potential from internal and external destabilizing factors $^{21}$. It does not understand the tools and means of such protection.

A rather common approach to determining the essence of economic security of an enterprise is to consider it as a certain state of corporate resources (resources of capital, personnel, information, technology, and

\footnotetext{
${ }^{18}$ Постанова Ради Центральної спілки споживчих товариств України «Про концепцію економічної безпеки споживчої кооперації України» від 12.11.2008. URL: http://zakon.nau.ua

${ }^{19}$ Іванюта Т. М., Заїчковський А. О. Економічна безпека підприємства : навч. посіб. [для студ. вищ. навч. закл.]. Київ : Центр учбової літера тури, 2009. 256 с.

${ }^{20}$ Васильців Т. Г., Волошин В. І., Бойкевич О. Р., Каркавчук В. В. Фінансово-економічна безпека підприємств України: стратегія та механізми забезпечення : монографія. Львів : Ліга-Прес, 2012. $386 \mathrm{c}$.

${ }^{21}$ Корчевська Л. О., Жосан Г. В. Методологічні питання економічної безпеки підприємства // Вісник економіки транспорту і промисловості. 2010. № 29. С. 108-110.
} 
equipment) and business opportunities, which guarantees their most efficient use for the stable functioning of dynamic scientific and technical and social development, prevention of internal and external negative influences (threats) ${ }^{22}$.

\subsection{Definition of the essential characteristics of the concept "economic security of the enterprise"}

On the basis of further research and systematization of the views of scientists, a list of essential characteristics used by scientists in considering the economic security of the enterprise (Table 1) was established.

Apparently, some scientists focus on one particular essential characteristic of the company's economic security, others - on several, more revealing the essence of the concept.

Thus, investigating the views of 44 scientists, found that 14 of them when considering the essence of economic security enterprises underline the state of corporate resources use (or the state of corporate resources). Such scientists are V. Heiets, S. Pokopropivny, Z. Varnalij, O. Kosarev, T. Kuzenko, N. Podluzhnaya, S. Ilyashenko, O. Grunin, V. Mak-Mak, A. Kiriyenko, L. Shvab, V. Muntian, I. Mantsurov, O. Nosinova. The share of these scientists in the total amount is $31.8 \%$. It is important to note that the approaches of these scientists point to the need to ensure the effective use of enterprise resources, that is, one can conclude that one of the prerequisites for ensuring an adequate level of economic security of the enterprise is the effectiveness of its activities.

In their works, 13 scientists emphasize the state of the protection of resources, capacity, business processes of the enterprise. Such scholars include F. Evdokimov, O. Mizina, S. Dovbnya, A. Beijing, L. Malyuta, V. Shlikov, D. Kovalev, Y. Krakos, I. Pletnikova, M. Bendikov, V. Zabrodsky, N. Podluzhna, A. Sosnin. The share of these scientists in the total amount is $29.5 \%$.

Among the investigated sources, three scientists (N. Yatsenko, S. Mikhailuk, B. Andrushkov) emphasize the economic state of the enterprise, which is consistent with internal and external changes in financial and economic activity, which ensures the protection of the interests of the enterprise from various threats. The share of these scientists in the total amount is $6.8 \%$.

\footnotetext{
22 Економіка підприємства : підручник / За заг. ред. С. Ф. Покропивного. Вид. 2-ге, перероб. та доп. Київ : КНЕУ, 2001. 528 с.
} 
Table 1

\section{Essential characteristics of the concept \\ "economic security of the enterprise"}

\begin{tabular}{|c|c|c|c|c|c|c|c|c|}
\hline Author & 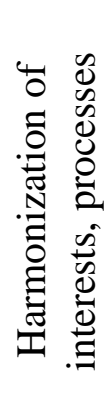 & 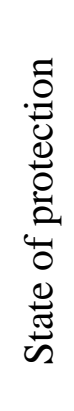 & 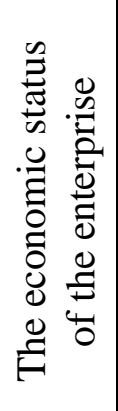 & 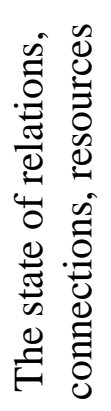 & 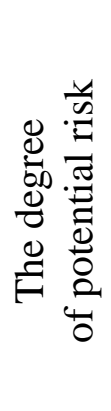 & 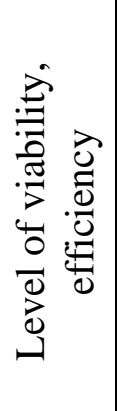 & 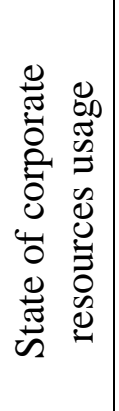 & 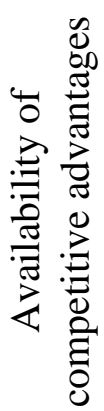 \\
\hline G. Kozachenko, V. Ponomarev & + & & & & & & + & \\
\hline $\begin{array}{l}\text { F. Evdokimov, O. Mizina, } \\
\text { S. Dovbnya, A. Beijing, } \\
\text { L. Malyuta, V. Shlikov, } \\
\text { D. Kovalev, Yu. Krakos, } \\
\text { I. Plitnikova, M. Bendikov, } \\
\text { V. Zabrodsky, A. Sosnin, } \\
\text { N. Podluzhna }\end{array}$ & & + & & & & & & \\
\hline F. Evdokimov & + & & & & & & & \\
\hline $\begin{array}{l}\text { N. Yatsenko, S. Mikhailuk, } \\
\text { B. Andrushkov }\end{array}$ & & & + & & & & & \\
\hline $\begin{array}{l}\text { Great Economic Dictionary } \\
\text { V.Zubik, A. Sudoplatov }\end{array}$ & & & & + & & & & \\
\hline T. Sokolenko & & & & & + & & & \\
\hline $\begin{array}{l}\text { "On the Concept of Economic } \\
\text { Security of Consumer } \\
\text { Cooperation of Ukraine" }\end{array}$ & & + & & & & & & \\
\hline T. Ivanuta, A. Zaichychsky & & + & & + & & & + & \\
\hline T. Vasiltsiv & & & & & & + & & \\
\hline L. Korchevskaya, G. Josan & & + & & & & & & \\
\hline $\begin{array}{l}\text { V. Heiets, O. Kosariev, } \\
\text { T. Kuzenko, N. Podluzhna, } \\
\text { S. Ilyashenko, O. Grunin, } \\
\text { V. Mak-Mak, A. Kiriienko, } \\
\text { L. Shvab, V. Muntiyan, } \\
\text { Z. Varnaliy, I. Mantsurov, } \\
\text { O. Nusinova, S. Pokropivny }\end{array}$ & & & & + & & & + & \\
\hline N. Lohanova & & & & & & & & + \\
\hline Number of references & 3 & 18 & 3 & 17 & 1 & 1 & 18 & 1 \\
\hline
\end{tabular}

Also, in three sources, namely, the Great Economic Dictionary and works of the authors V. Zubik and A. Sudoplatov, points to the state of relations, ties, resources, characterizing the economic security of the enterprise. The share of these scientists in total is also $6.8 \%$. 
Two scientists from 44 emphasized the following characteristic of the economic security of the enterprise as the harmonization of interests, processes (G. Kozachenko, V. Ponomarev), the state of security, the state of relations, connections, resources, their use ( $T$. Ivanyuta, A. Zaichchkovsky), the state of protection (L. Korchevskaya, G. Josan). Their share is $4.5 \%$.

All other characteristics are found in the work of one scientist from 44: the harmonization of interests, processes (F. Evdokimov), the state of security ("On the Concept of Economic Security of Consumer Cooperation in Ukraine"), the degree of potential risk (T. Sokolenko), the level of viability, efficiency (T. Vasiltsov), the presence of competitive advantages (N. Lokhanova). The share of these scientists in the total amount also makes up to $2.3 \%$.

It will also be appropriate to analyse the number of references to some or other essential characteristics of the enterprise's economic security in all investigated scientists (as some scientists point to several characteristics) (Fig. 1).

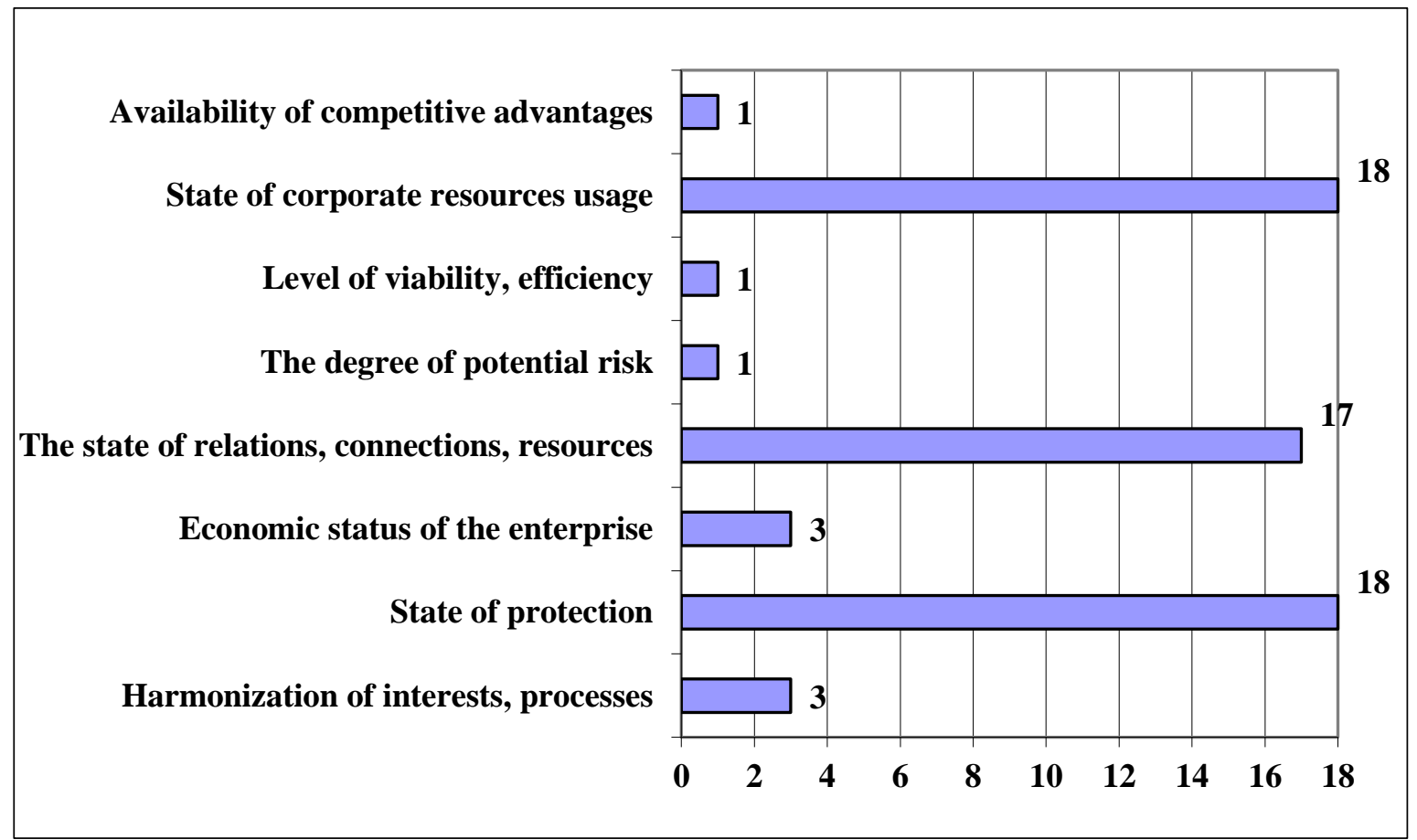

Fig. 1. The frequency of mentioning the essential characteristics of economic security of the enterprise in the investigated works

Selecting the most significant characteristics of the concept, it is expedient to apply the method of expert assessments while the subjective opinions of experts will be their emphasis on the essential characteristics 
of the enterprise's economic security. As the researchers note, the examination procedure is based on the use of the method of pairwise comparison of objects, according to which they are all compared in pairs. The method of pairwise comparisons has become widely used in the investigated economic phenomena since it allows us to determine the most important priorities of choice, which provides an opportunity for further deeper analysis.

Applying the pairwise comparison method, each essential characteristic, relative to another, is assigned a coefficient of relative importance, which can be established by experts or determined on the basis of their comparison according to a certain criterion, which in our case may be the frequency of mentioning the essential characteristics of economic security of the enterprise in the investigated works.

Let's place all the essential characteristics we are investigating in order of decreasing the frequency of their mention in the work of scientists and assign them an identification code (Table 2).

Table 2

Ranking of the essential characteristics of economic security of the enterprise in the investigated works

\begin{tabular}{|l|c|c|}
\hline \multicolumn{1}{|c|}{ Characteristic } & $\begin{array}{c}\text { Identification } \\
\text { code }\end{array}$ & $\begin{array}{c}\text { Frequency } \\
\text { of } \\
\text { mentioning }\end{array}$ \\
\hline The state of protection & $\mathrm{X} 1$ & 18 \\
\hline The state of corporate resources use & $\mathrm{X} 2$ & 18 \\
\hline $\begin{array}{l}\text { The state of relations, connections, } \\
\text { resources }\end{array}$ & $\mathrm{X} 3$ & 17 \\
\hline Harmonization of interests, processes & $\mathrm{X} 4$ & 3 \\
\hline The economic status of the enterprise & $\mathrm{X} 5$ & 3 \\
\hline The degree of potential risk & $\mathrm{X} 6$ & 1 \\
\hline Level of viability, efficiency & $\mathrm{X} 7$ & 1 \\
\hline Availability of competitive advantages & $\mathrm{X} 8$ & 1 \\
\hline
\end{tabular}

Based on the data of Tab. 2, the matrix of pairwise comparisons of the essential characteristics of the economic security of the enterprise is filled, the sum of coefficients of relative importance is calculated and determined by the weight of the essential characteristic (Table 3 ).

Based on the results of calculating the importance of the essential characteristics of economic security, the enterprise is offered a choice of 
characteristics that are essential for our study. According to the expert survey, the minimum allowable value of the weight, in which this characteristic can be considered significant, is 0.1. All specifications with lower weight are not significant and can be ignored during further research.

Table 3

Matrix of pairwise comparisons of essential characteristics of economic security of an enterprise

\begin{tabular}{|c|c|c|c|c|c|c|c|c|c|c|}
\hline$\frac{0}{8}$ & $\bar{x}$ & $\tilde{x}$ & $\tilde{x}$ & $\ddot{x}$ & 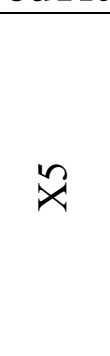 & $\ddot{x}$ & $\bar{x}$ & $\ddot{x}$ & 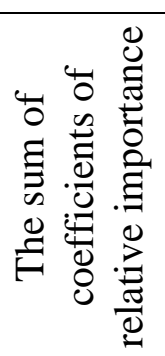 & 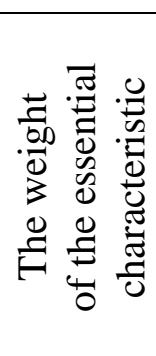 \\
\hline $\mathrm{X} 1$ & 1,00 & 1,00 & 1,06 & 6 & 6 & 18 & 18 & 18 & 69,06 & 0,290 \\
\hline $\mathrm{X} 2$ & 1,00 & 1,00 & 1,06 & 6 & 6 & 18 & 18 & 18 & 69,06 & 0,290 \\
\hline X3 & 0,94 & 0,94 & 1,00 & 5,67 & 5,67 & 17 & 17 & 17 & 65,22 & 0,274 \\
\hline $\mathrm{X} 4$ & 0,17 & 0,17 & 0,18 & 1,00 & 1 & 3 & 3 & 3 & 11,51 & 0,048 \\
\hline $\mathrm{X} 5$ & 0,17 & 0,17 & 0,18 & 1,00 & 1,00 & 3 & 3 & 3 & 11,51 & 0,048 \\
\hline X6 & 0,06 & 0,06 & 0,06 & 0,33 & 0,33 & 1,00 & 1,00 & 1,00 & 3,84 & 0,016 \\
\hline $\mathrm{X} 7$ & 0,06 & 0,06 & 0,06 & 0,33 & 0,33 & 1,00 & 1,00 & 1,00 & 3,84 & 0,016 \\
\hline $\mathrm{X} 8$ & 0,06 & 0,06 & 0,06 & 0,33 & 0,33 & 1,00 & 1,00 & 1,00 & 3,84 & 0,016 \\
\hline \multicolumn{9}{|c|}{ Total } & 237,87 & 1,000 \\
\hline
\end{tabular}

Consequently, the essential characteristics of the economic security of an enterprise whose weight exceeds 0.1 include:

1. State of protection $(0,29)$.

2. Condition of corporate resources' use $(0,29)$.

3. Status of relations, connections, resources $(0,274)$.

These characteristics can be divided into two groups:

1. Functional (use of corporate resources).

2. Effective (state of protection, state of relations, connections, resources).

\subsection{Preconditions for the formation of a proper level of economic security of the enterprise}

As has been established, the security level is determined by the efficiency of the use of resources. In turn, this efficiency is determined primarily by the ability of the enterprise's management system to attract, form, redistribute, and use the necessary resources. Thus, the economic 
security of an enterprise depends on how efficiently its management and managers will be able to avoid possible threats and eliminate the harmful effects of the influence of individual factors of the external and internal environment.

Thus, the economic security of an enterprise is a state of the enterprise's management system, which achieves efficient resource management and is able to respond adequately to changes in the external and internal environment and to project potential threats and reactions to them in order to ensure the company's non-crisis development. After all, it is the management system that recognizes threats and develops measures to overcome them. At the same time, the level of economic security is determined by the extent to which the management of the company and its managers are able to prevent possible threats and avoid losses from the negative effects of factors.

The research on the interconnection of the preconditions for the formation of the appropriate level of economic security of the enterprise was made: efficiency, innovation and competitiveness. It is established that the basis of enterprise competitiveness is the innovation and efficiency of its activity. And not only (but above all) profit and indicators of the ratio of income and expenditure but also organizational and managerial efficiency. And this makes it possible to link together in a single whole such key characteristics of the enterprise's activities as efficiency and competitiveness.

Such a complex combination of the above characteristics of the enterprise will allow developing a set of strategic, tactical, and operational measures aimed at ensuring sustainable development of the enterprise, with the aim of increasing the competitiveness of the national economy and raising the standard of living.

The results of the research showed that there are interconnections between the three main characteristics of the company's activity efficiency, competitiveness, and economic security. In the process of reviewing the main characteristics, a systematic approach was used to investigate the causal relationships between the enterprise's economic security (purpose), the competitiveness of the enterprise (means) and efficiency (the ratio of income and expenditure, organizational and managerial efficiency), and the innovation of its activities (tools) (Fig. 2).

Such a comprehensive presentation will enable systematically to approach the definition of the directions of ensuring an adequate level of economic security of the enterprise. 


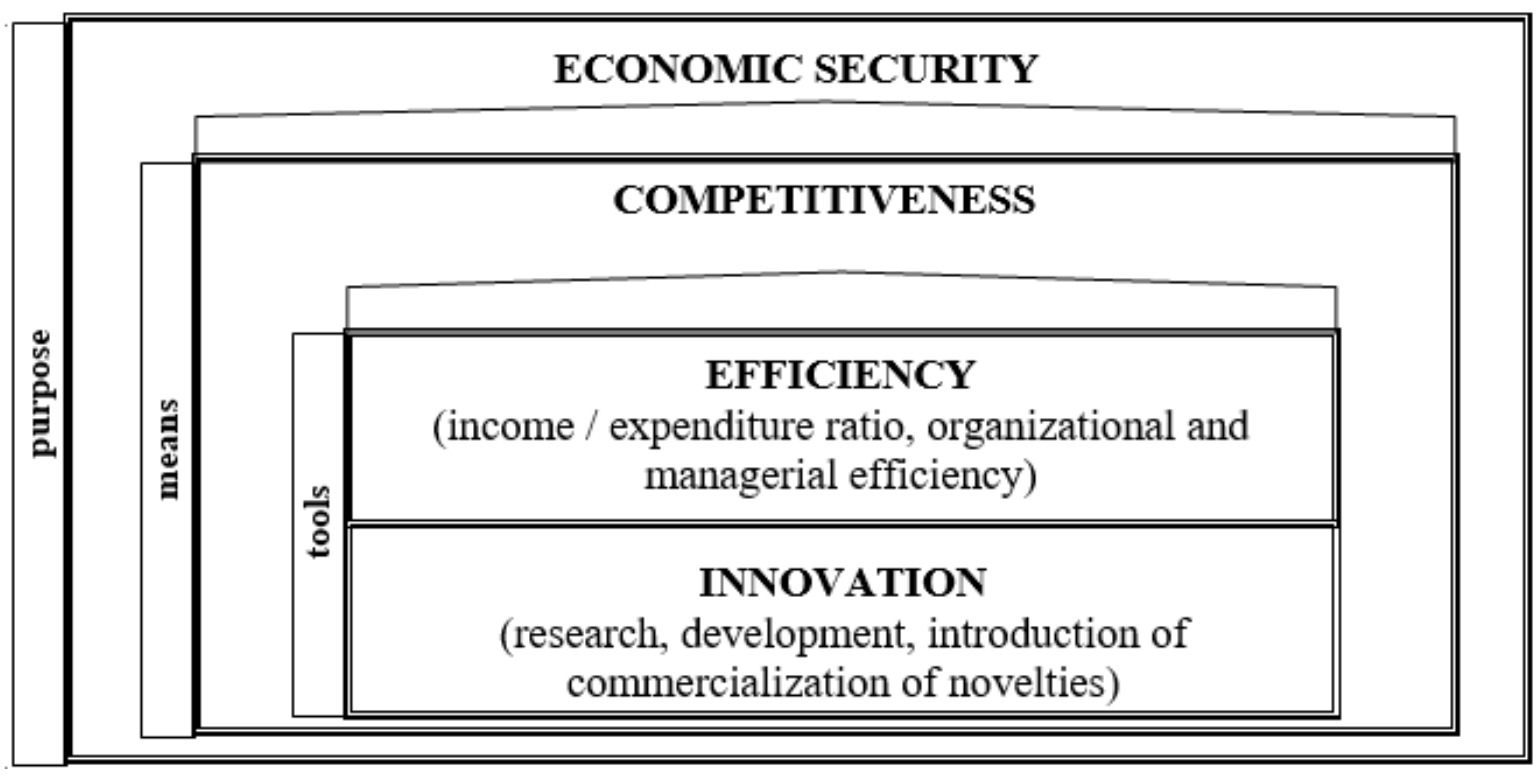

Fig. 2. The preconditions for the formation of a proper level of economic security of the enterprise and their interconnection

\section{CONCLUSIONS}

A semantic analysis of the essence of the concept "economic security of the enterprise" was conducted, which made it possible to form an exhaustive list of essential characteristics used by scientists during its definition. According to the results of the examination, which is based on the use of the method of pairwise comparisons, those essential characteristics that are significant are identified and singled out. The established characteristics are divided into functional (corporate resources usage) and productive (state of security, state of relations, connections, resources).

It is established that the level of security is determined primarily by the efficiency of the use of resources, which greatly depends on the ability of the enterprise's management system to attract, form, redistribute, and use the necessary resources. Thus, the economic security of an enterprise depends on how effective its management and managers will be able to avoid possible threats and eliminate the harmful effects of the influence of individual factors of the external and internal environment.

The interconnection of the preconditions of the formation of the proper level of economic security of the enterprise - efficiency, innovation, and competitiveness - was studied. The hierarchy of these preconditions is established, namely, that the basis of the company's 
competitiveness lies in the innovation and efficiency of its activities. The highest level that characterizes the result to be achieved is economic security, which ensures the crisis-free development of the enterprise.

\section{SUMMARY}

The article gives an overview of theoretical and methodical approaches to the definition of the essence of economic security of the enterprise. On the basis of semantic analysis, essential characteristics of the concept "economic security of the enterprise", which include the state of security; state of use of corporate resources; the state of relations, connections, resources were defined. The established characteristics are divided into functional and productive. The obtained results provided an opportunity to consider the preconditions for the formation of an appropriate level of economic security of the enterprise (as a goal), which includes competitiveness (as a means) and efficiency and innovation (as tools). The proposed complex view will allow systematically approaching the definition of the directions of ensuring an adequate level of economic security of the enterprise.

\section{REFERENCES}

1. Бендиков М. А. Экономическая безопасность промышленного предприятия в условиях кризисного развития. Менеджмент в России и за рубежом. 2000. № 2. С. 17-30.

2. Большой экономический словарь / под ред. А. Н. Азриляна. Москва : 5-е изд., доп. и перераб., 2002. 1280 с.

3. Грунин О. А. Экономическая безопасность организации : учеб. пособ. СПб.; М.; Х.; Минск, 2002. 160 с.

4. Довбня С. Б., Гічова Н. Ю. Діагностика рівня економічної безпеки підприємства. Фінанси України. 2008. № 4. С. 88-97.

5. Евдокимов Ф. И. Экономическая безопасность - необходимое звено в планировании развития предприятия. Донбас-2002: наука $\mathrm{i}$ техніка - виробництву : матеріали наук.-практ. конф., 5-6 лютого 2002 р., Донецьк. С. 966-969.

6. Евдокимов Ф. И., Мизина Е. В. Экономическая устойчивость предприятия как фактор его безопасности. Наукові пращі Донецького державного технічного університету. Серія: економічна. 2001. Вип. 37. С. 16-25.

7. Економіка підприємства : підручник / за ред. С. Ф. Покропивного. Київ : КНЕУ, 2001. 526 с. 
8. Економічна безпека : навч. посіб. / за ред. 3. С. Варналія. Київ : Знання, 2009. 647 с.

9. Економічна безпека : підручник / за ред. О. І. Барановського, О. Б. Жихор. Київ : УБС НБУ, 2015. 467 с.

10. Економічна та майнова безпека підприємства i підприємництва. Антирейдерство / за ред. Б. М. Андрушківа. Тернопіль : Терно-граф, 2008. 424 с.

11. Забродский В. Теоретические основы оценки экономической безопасности отрасли и фирмы. Бизнес-информ. 1999. № 15-16. С. 35-37.

12. Зубик В. Б., Зубик Д. В. Экономическая безопасность предприятия (фирмы). Минск : Высшая школа, 1998. 391 с.

13. Ильяшенко С. И. Составляющие экономической безопасности предприятия и подходы к их оценке. Актуальні проблеми економіки. 2003. Вип. 3 (21). С. 12-19.

14. Іванюта Т. М., Заїчковський А. О. Економічна безпека підприємства : навч. посіб. Київ, 2009. 256 с.

15. Камлик М. I. Економічна безпека підприємницької діяльності. Економіко-правовий аспект : навч. посіб. Київ, 2005. $432 \mathrm{c}$.

16. Кірієнко А. В. Механізм досягнення i підтримки економічної безпеки підприємства : автореф. дис. на здобуття наук. ступня канд. екон. наук : 08.06.01. Київ, 2000. 19 с.

17. Ковальов Д., Плєтнікова I. Кількісна оцінка рівня економічної безпеки підприємства. Економіка України. 2000. № 4. C. $35-40$.

18. Козаченко А. В. Экономическая безопасность предприятия: сущность и механизм обеспечения. Київ, 2003. 280 с.

19. Козаченко Г. В., Пономарьов В. П. Економічна безпека підприємств: сутність і передумови формування. Теорія та практика управління у трансформачійний період. 2001. Т. 3. 2001. C. 3-7.

20. Корчевська Л. О., Жосан Г. В. Методологічні питання економічної безпеки підприємства. Вісник економіки транспорту і промисловості. 2010. Вип. 29. С. 108-110.

21. Косарєв О. Й., Захаров О. І., Рибак О. М. Людський капітал як ключовий чинник забезпечення економічної безпеки підприємства. Актуальні проблеми економіки. 2008. Вип. 9. C. 104-113. 
22. Кракос Ю. Б. Подход к оценке уровня финансовой составляющей экономической безопасности предприятия. Економіка. Фінанси. Право. 2006. № 12. С. 7-12.

23. Кузенко Т. Б. Планування економічної безпеки підприємств в умовах ринкової економіки : дис. канд. екон. наук : 08.06.01 / Європейський ун-т фінансів, інформаційних систем, менеджменту i бізнесу. Київ, 2003. 194 с.

24. Кузенко Т. Б. Тактичне i стратегічне планування економічної безпеки підприємства. Актуальні проблеми економіки. 2004. Вип. 3. С. 142-151.

25. Лоханова Н. О. Система управління станом економічної безпеки підприємства: проблемні питання, концепція розвитку. Економіст. 2005. № 2. С. 52-56.

26. Мак-Мак В. П. Служба безопасности предприятия. Организационно-управленческие и правовые аспекты деятельности. Москва : Мир безопасности, 1999. 160 с.

27. Малюта Л. Я. Економічна безпека підприємств в умовах становлення ринкових відносин. Економіка. Фінанси. Право. 2008. № 10. C. $14-17$.

28. Манцуров I. Г., Нусінова О. В. Побудова ієрархічної структури складових економічної безпеки підприємств. Ефективна економіка. 2011. № 9. URL: http://www.economy.nayka.com.ua/ index.php?op=1\&z=680 (дата звернення 14.05.2019).

29. Моделювання економічної безпеки: держава, регіон, підприємство : монографія / за ред. В. М. Геєць. Харків : ІНЖЕК, 2006. $240 \mathrm{c}$.

30. Мунтіян В. I. Економічна безпека України : монографія. Київ : КВІЦ, 1999. 463 с.

31. Пекін А. Економічна безпека підприємств як економікоправова категорія. Економіст. 2007. № 8. С. 23-26.

32. Плєтнікова I. Л. Визначення рівня і забезпечення економічної безпеки залізниці : автореф. дис. на здобуття наук. ступня канд. екон. наук : 08.07.04. Харків, 2001. 15 с.

33. Подлужна Н. О. Вибір критерія економічної безпеки підприємства. Наукові праиі Донеиького державного технічного університету. 2002. № 46. С. 10-16.

34. Подлужна Н. О. Організація управління економічною безпекою підприємства : автореф. дис. на здобуття наук. ступеня канд. екон. наук : 08.06.01. Донецьк, 2003. 16 с. 
35. Пономарьов В. П. Формування механізму забезпечення економічної безпеки підприємства: автореф. дис. на здобуття наук. ступня канд. екон. наук : 08.06.01. Луганськ, 2000. 20 с.

36. Постанова Ради Центральної спілки споживчих товариств України «Про концепцію економічної безпеки споживчої кооперації України» від 12.11.2008. URL: https://zakon.rada.gov.ua/ $\mathrm{rada} / \mathrm{show} / \mathrm{ru} / \mathrm{n} 0007626-08$ (дата звернення 14.05.2019).

37. Соколенко Т. М. Економічна безпека підприємства в умовах транзитивної економіки. Наука і життя: сучасні тенденції, інтеграція у світову наукову думку: матеріали VII Міжнар. наук.практ. інтернет-конф. 19-21 травня 2011 р. Київ, 2011. URL: http://intkonf.org/kand-ped-n-sokolenko-tm-ekonomichna-bezpekapidpriemstva-v-umovahtranzitivnoyi-ekonomiki

38. Соснин А. С., Прыгунов П. Я. Менеджмент безопасности предпринимательства. Киев : Изд-во Европ. ун-та, 2004. 357 с.

39. Судоплатов А. П., Лекарев С. В. Безопасность предпринимательской деятельности : практ. пособие. Москва : ОЛМАПРЕСС, 2001. $381 \mathrm{c}$.

40. Фінансово-економічна безпека підприємств України: стратегія та механізми забезпечення: монографія / за ред. Т. Г. Васильціва. Львів : Ліга-Прес, 2012. 386 с.

41. Шваб Л. І. Економіка підприємства: підручник. Київ : Каравела, 2011. 416 с.

42. Шлыков В. В. Комплексное обеспечение экономической безопасности предприятия. Санкт-Петербург : Алетейя, 1999. 138 с.

43. Яценко Н. М., Михайлюк С. О. Регіональна економічна безпека у контексті національної економічної безпеки. Наукові праці Донецького державного технічного університету. Серія: економічна. 2001. Вип. 37. С. 78-82.

Fisunenko P. A. Ph.D. in Economics, Associate Professor, Department of Accounting, Economics and Personnel Management of Enterprise, Prydniprovska State Academy of Civil Engineering and Architecture, Ukraine 